\title{
PENINGKATAN KEMAMPUAN PEMECAHAN MASALAH MATEMATIS SISWA MELALUI MODEL PEMBELAJARAN KNISLEY BERBANTUAN MEDIA JING-JING BAR
}

\author{
Lilik Indah Sari ${ }^{1}$, Henri Suryo Bintoro ${ }^{2}$, Jayanti Putri Purwaningrum ${ }^{3}$ \\ ${ }^{1}$ Program Studi PGSD, FKIP, Universitas Muria Kudus \\ Sarililik84@gmail.com \\ ${ }^{2,3}$ Program Studi Pendidikan Matematika, FKIP, Universitas Muria Kudus
}

\begin{abstract}
ABSTRAK
Tujuan penelitian ini adalah untuk meningkatkan kemampuan pemecahan masalah matematis, melalui model pembelajaran Knisley berbantuan media jing-jing bar. Penelitian ini merupakan penelitian tindakan kelas yang dilakukan di kelas V SDN 01 Bakalan Krapyak Kecamatan Kaliwungu Kabupaten Kudus semester II tahun pelajaran 2019/2020. Metode penelitian tindakan kelas yang terdiri dari 2 siklus masing-masing siklus terdiri dari 4 tahapan yaitu perencanaan, pelaksanaan, pengamatan dan refleksi. Instrument yang digunakan dalam penelitian ini adalah tes kemampuan pemecahan masalah matematis. Teknik analisis data yang digunakan dalam penelitian ini adalah data kuantitatif. Hasil penelitian menunjukkan Kemampuan pemecahan masalah matematis melalui Model Pembelajaran Knisley berbantuan media jing-jing bar mengalami peningkatan sebesar 50,13 dari kondisi awal 31,67 menjadi 81,8 pada kondisi akhir
\end{abstract}

Kata Kunci : Pemecahan Masalah Matematis, Model Pembelajaran Knisley, Media Jing-jing Bar

\begin{abstract}
The purpose of this study is to improve mathematical problem solving skills, through the Knisley learning model assisted by the jing-bar media. This research is a classroom action research conducted in class $V$ SDN 01 Bakalan Krapyak Kaliwungu District Kudus Regency second semester 2019/2020 academic year. Classroom action research method consisting of 2 cycles each cycle consisting of 4 stages, namely planning, implementation, observation and reflection. The instrument used in this study was a test of mathematical problem solving ability. The data analysis technique used in this study is quantitative data. The results showed, among others: (1) The ability to solve mathematical problems through the Knisley Learning Model assisted by the jing-bar media increased by 50.13 from the initial condition of 31.67 to 81.8 in the final condition.
\end{abstract}

Keywords: Mathematical Problem Solving, Knisley's Learning Model, Jing-jing Bar Media 


\section{PENDAHULUAN}

Masalah yang kerap dihadapi pada sebuah pembelajaran matematika yaitu terkait dengan prestasi belajar pada siswa. Terdapat beberapa factor yang mempengaruhi prestasi belajar siswa dalam pembelajaran matematika salah satunya yaitu kemampuan pemecahan masalah matematis siswa yang rendah dalam memecahkan masalah yang telah diberikan. Kemampuan pemecahan masalah matematis siswa yang rendah mempengaruhi prestasi belajar siswa itu sendiri. Terdapat beberapa hal yang dapat menyebabkan rendahnya kemampuan pemecahan masalah matematis siswa diantaranya yaitu media atau alat pembelajaran yang digunakan, metode pembelajaran yang diterapkan oleh guru dalam sebuah pembelajaran, serta lingkungan belajar. Selain itu permasalahan rendahnya kemampuan pemecahan masalah matematis menurut Kurniad dan Purwaningrum (dalam Novitasari 2020) bahwa rendahnya kemampuan pemecehan masalah matematis dikarenakan siswa tidak bisa memahami masalah dan tidak bisa melakukan operasi hitung dengan baik.

Hal tersebut sesuai dengan hasil wawancara dengan guru kelas V serta observasi yang dilaksanakan oleh peneliti di SDN 01 Bakalan Krapyak yang mengatakan bahwa salah satu masalah yang dihadapi guru dalam pembelajaran matematika yaitu kemampuan pemecahan masalah matematis siswa yang masih sangat rendah. Hal tersebut dikarenakan oleh beberapa faktor antara lain yaitu kurangnya media yang terdapat di sekolah tersebut, dan pemilihan model dan metode pembelajaran yang monoton sehingga menyebabkan siswa cenderung pasif dalam melaksanakan pembelajaran. Hasil wawancara tersebut juga diperkuat dengan adanya observasi yang dilaksanaka oleh peneliti. Pada saat pembelajaran matematika berlangsung siswa cenderung lebih pasif, tidak memperhatikan guru ketika menjelaskan seta siswa tidak semangat dalam melaksanakan pembelajaran.

Informasi lain yang didapat dari wawancara dengan guru kelas V SDN 01
Bakalan Krapyak yaitu kurangnya kemampuan menyelesaikan soal cerita. Hal tersebut terlihat dari rata-rata hasil prasiklus yang menunjukkan bahwa kemampuan pemecahan masalah matematis siswa masih sangat rendah yaitu 37,67. Siswa masih sangat kesulitan dalam mememcahkan masalah yang diberikan oleh guru dan memecahkan masalah yang dalam bentuk soal cerita yang telah disesuaikan dengan indikator pemecahan masalah matematis.

Terdapat beberapa indikator pemecahan masalah matematis siswa, Polya (dalam Purwaningrum 2018) menjelaskan terdapat 4 indikator pemecahan masalah matematis siswa, yaitu: (1) understanding the problem (memahami masalah); (2) devising a plan (merencanakan masalah); (3) carrying out the plan (melaksanakan rencana); (4) looking back (memeriksa kembali proses dan hasil). Maryam (dalam Cahyani, Setyawati 2016) mengatakan bahwa pemecahan masalah matematis siswa merupakan salah satu elemen penting bagi siswa dalam menyelesaikan masalah dalam kehidupan nyata.

Salah satu cara untuk memecahkan masalah tersebut adalah dengan menggunakan metode pembelajaran yang sesuai serta menggunakan media pembelajaran yang tepat. Sehingga pembelajaran akan menjadi lebih efektif, membuat pembelajaran menjadi menyenangkan serta membuat siswa lebih aktif dalam menjalankan pembelajaran. Untuk meningkatkan kemampuan pemecahan masalah matematis siswa serta membuat siswa lebih aktif dalam pembelajaran peneliti menerapkan model pembelajaran matematika Knisley.

Model pembelajaran Knisley merupakan salah satu model pembelajaran kooperatif. Dalam hal ini siswa dituntut untuk lebih aktif berbicara serta siswa diminta untuk berpikir lebih dalam dan memperluas kemampuan pemecahan masalah matematis siswa melalui pengerjaan soal serta pemberian kuis ataupun tugas. Knisley (dalam Purnamasari 2016) mengatakan bahwa model pembelajaran yang dituntut pada kurikulum 2006 adalah model pembelajaran matematika Knisley. Mulyana (dalam 
Karunia 2016) menjelaskan bahwa model pembelajaran matematika Knisley merupakan model pembelajaran matematika yang terdiri dari empat tahap, yaitu pembelajaran ketika guru berperan sebagai pencerita, guru sebagai pembimbing dan motivator, guru sebagai narasumber, dan guru sebagai pelatih. Hartaman (dalam Aditya, dkk 2012) menjelaskan tahapan-tahapan model pembelajaran Knisley yaitu kongkritreflektif, kongkrit-aktif, abstrak-reflektif, abstrak-aktif.

Sintaks atau langkah-langkah model pembelajaran matematika Knisley sebagai berikut (Karunia, 2016): (1) Siswa merumuskan konsep beru berdasarkan konsep yang telah diketahuinya dan belum dapat membedakan konsep baru dengan konsep yang telah dikuasi; (2) Siswa mencoba untuk mengukur, menggambar, menghitung, dan membandingkan untuk membedakan konsep baru dengan konsep lama yang telah diketahuinya; (3) Siswa menginginkan algoritma dengan penjelasan yang masuk akal, menyelesaikan masalah dengan suatu logika, melangkah tahap demi tahap dimulai dengan asumsi awal dan suatu kesimpulan sebagai logika; (4) Siswa menyelesaikan masalah dengan konsep yang telah dibentuk.

Peneliti memilih model pembelajaran Knisley karena siswa dapat memiliki banyak kesempatan belatih dalam menjawab pertanyaan sehingga siswa akan lebih mudah memahami materi yang dipelajari sehingga siswa menjadi mudah untuk memecahkan masalah yang diberikan oleh guru, siswa lebih banyak memiliki kesempatan untuk memanfaatkan keterampilan serta pengetahuannya secara komprehensif, dan siswa dapat memecahkan masalah dengan menggunakan konsep yang siswa temukan.

Supaya pembelajaran menjadi lebih menyenangkan, peneliti melengkapinya dengan menggunakan media jing-jing bar. Media jing-jing bar ini memiliki kepanjangan dari jaring-jaring bangun ruang, media jing-jing bar ini merupakan media yang diadopsi dari permainan bongkar pasang. Masruroh (2013) menyatakan bahwa media bongkar pasang merupakan media dua dimensi yang besifat visual karena dalam penggunaannya lebih memanfaatkan indera penglihatan. Media bongkar pasanag ini mempunyai konsep seperti permainan pada puzzle akan tetapi telah mendapatkan modifikasi di bagian tertentu sehingga sesuai dengan materi pembelajaran dan tujuan pembelajaran yang hendak dicapai.

Dengan menggunakan model pembelajaran Knisley dengan berbantuan media jing-jing bar diharapkan kemampuan pemecahan masalah matematis siswa dapat meningkat. Dengan penggunaan model pembelajaran Knisley yang memiliki tujuan memperdalam pemahaman materi serta pemecahan masalah siswa dengan cara pemberian soal ataupun kuis dengan disertai media jing-jing bar yang menarik siswa diharapkan dapat menarik minat siswa dalam menjalankan pembelajaran sehingga siswa lebih aktif serta dapat meningkatkan kemampuan pemecahan masalah matematis siswa.

Berdasarkan uraian di atas, maka rumusan masalah penelitian ini adalah: (1) Bagaimana peningkatan kemampuan pemecahan masalah matematis siswa menggunakan model pembelajaran Knisley berbantuan media jing-jing bar pada kelas V SD 01 Bakalan Krapyak. Tujuan penelitian ini adalah untuk; (1) peningkatan keterampilan guru dalam meningkatkan kemampuan pemecahan matematis masalah.

\section{METODE PENELITIAN}

Penelitian ini merupakan penelitian tindakan kelas yang dilakukan di SD 01 Bakalan Krapyak, Kecamatan Kaliwungu, Kabupate Kudus pada semester II tahun pelajaran 2019/2020. Penelitian tindakan kelas ini terdiri dari 2 siklus yang masingmasing siklus terdapat 4 tahapan yaitu perencanaa, pelaksanaan, pengamatan serta refleksi. Subjek penelitian berjumlah 22 siswa yang terdiri dari 10 siswa perempuan dan 12 siswa laki-laki.

Penelitian tindakan kelas ini dilaksanakan mulai bulan November 2019 sampai Juni 2020. Langkah awal yang disiapkan dalam penelitian ini yaitu mempersiapkan proposal dan instrumen 
penelitian pada bulan Desember sampai bulan Februari 2020 dilanjutkan pelaksanaan pembelajaran siklus I dan siklus II pada bulan Maret 2020 dan dilanjutkan dengan menyusun laporan pada bulan April sampai Juni 2020.

Teknik pengumpulan data yang digunakan dalam penelitian ini yaitu teknik test serta non tes. Tes yang dilaksanakan yaitu tes kemampuan pemecahan masalah matematis yang dilaksanakan pada pertemuan ke-3, dan non tes yang dilaksanakan yaitu wawancara serta dokumentasi. Teknik analisis data yang digunakan yaitu teknik analisis data kuantitatif. Teknik analisis data kuantitatif digunakan untuk menghitung rata-rata nilai serta ketuntasan belajar.

\section{HASIL DAN PEMBAHASAN}

\section{Kemampuan Pemecahan Masalah} Matematis Siswa
Untuk mengetahui kondisi awal subjek penelitian, peneliti melaksanakan prasiklus yang dilaksankan sebelum penelitian. Tujuan dari prasiklus ini yaitu untuk mengetahui kemampuan pemecahan masalah matematis siswa yang dilaksanakan dengan pemberian soal tes prasiklus. Dari hasil analisis data prasiklus menunjukkan bahwa kemampuan pemecahan masalah matematis siswa masih sangat rendah. Setelah memperoleh hasil data prasiklus kemampuan pemecahan masalah matematis siswa selanjutnya peneliti melakukan penelitian siklus I dan siklus II.

Berikut perbandingan hasil tes kemampuan pemecahan masalah matematis siswa pada kondisi awal (prasiklus) dengan kondisi akhir (siklus II), disajikan pada tabel 1 berikut.

Tabel 1. Hasil Prasiklus Kemampuan Pemecahan Masalah Matematis Siswa

\begin{tabular}{cccc}
\hline No & Keterangan & Kondisi Awal & Kondisi Akhir \\
\hline 1. & Nilai Tertinggi & 37,5 & 98 \\
2. & Nilai Terendah & 6,2 & 80 \\
3. & Rata-rata & 12,07 & \\
4. & Siswa Tuntas & 0 & 20 \\
5. & Siswa Tidak Tuntas & 22 & 2 \\
\hline
\end{tabular}

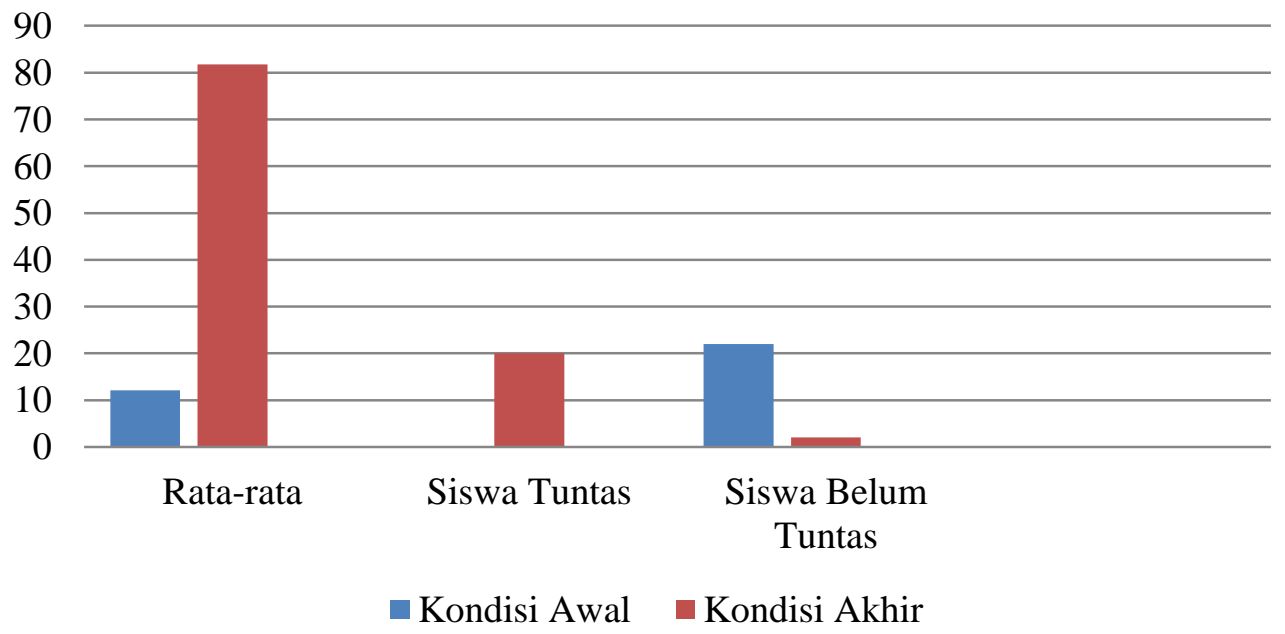

Gambar 1. Perbandingan hasil kemampuan pemecahan masalah matematis siswa kondisi awal dan kondisi akhir 
Setelah dilakukannya penelitian dengan menerapkan model pembelajaran Knisley berbantuan media jing-jing bar Kemampuan pemecahan masalah matematis siswa mengalami peningkatan 50,13 yang ditunjukkan dengan rata-rata nilai siswa dari kondisi awal 31,67 menjadi 81,8 pada kondisi akhir. Peningkatan kemampuan pemecahan masalah matematis ini dipengaruhi oleh beberapa faktor. Salah satunya yaitu pemilihan model pembelajaran yang tepat dengan menerapkan model pembelajaran Knisley.

Menurut Kusmiyanti (dalam Simamora, 2017) model pembelajaran matematika Knisley memiliki kelebihan sebagai berikut: (1) Meningkatkan semangat siswa untuk berfikir aktif untuk menyatakan pendapat; (2) Membantu suasana belajar yang kondusif karena siswa bersandar pada penemuan individu; (3) Memunculkan kegembiraan dalam proses belajar mengajar karena siswa dinamis dan terbuka dari berbagai arah. Sama halnya dengan pendapat Endang, dkk (dalam Anggreavi, 2016) bahwa kelebihan model pembelajaran matematika Knisley adalah: (1) Memudahkan mengidentifikasi tingkat pemahaman peserta didik ketika pembelajaran berlangsung.; (2) Terjadi pergantian tingkat keaktifan antara guru dengan peserta didik, sehingga pembelajaran tidak hanya berpusat kepada guru saja dan terjadinya interaksi dengan sesama teman maupun guru jika dilakukan secara berkelompok; (3) Model pembelajaran Knisley memuat aktivitas eksplorasi, elaborasi, dan konfirmasi yang menganut paradigma pembelajaran; (4) Suasana pembelajaran menjadi menyenangkan dan tidak tegang.

Selain pemilihan model pembelajaran yang tepat, penggunaan media pembelajaran jing-jing bar juga sangat mempengaruhi keberhasilan pembelajaran. Siswa sangat antusias ketika memainkan media tersebut. Dengan bantuan media pembelajaran yang tepat pembelajaran akan menjadi lebih efektif serta menyenangkan sehingga tujuan pembelajaran yang diharapkan tercapai. Halnya sependapat dengan Mujiani (2016) menjelaskan bahwa media pembelajaran yang tepat dan sesuai yang disajikan guru sangat membantu siswa dalam mencapai kompetensi dasar pada pelajaran matematika.

\section{KESIMPULAN}

Berdasarkan hasil penelitian serta pembahasan yang telah diuraikan dapat disimpulkan bahwa (1) Kemampuan pemecahan masalah matematis siswa kelas V SD 01 Bakalan Krapyak pada pembelajaran matematika dengan menerapkan model pembelajaran matematika Knisley berbantuan media jingjing bar mengalami peningkatan dengan kemampuan pemecahan masalah matematis siswa yang telah mencapai indikator keberhasilan yaitu mencapai ketuntasan klasikal lebih dari $75 \%$ dengan jumlah jumlah siswa adalah 19 siswa; (2) Aktivitas belajar siswa kelas V SD 01 Bakalan Krapyak pada pembelajaran matematika dengan menerapkan model pembelajaran matematika Knisley berbantuan media jingjing bar mengalami peningkatan dengan kemampuan pemecahan masalah matematis siswa telah mencapai indikator keberhasilan yaitu dengan ketuntasan klasikal lebih 75\% dengan minimal jumlah siswa adalah 19 siswa; (3) Keterampilan mengajar guru pada pembelajaran matematika dengan menerapkan model pembelajaran matematika Knisley berbantuan media jingjing bar mengalami peningkatan dengan mencapai indikator keberhasilan dengan persentase $\geq 70$ dengan minimal masuk dalam kategori terampil.

\section{DAFTAR PUSTAKA}

Aditya, Mulyana, Kutiawan. 2012. Implementasi Model

Pembelajaran Matematika

Knisley Dalam Upaya

Meningkatkan Kemampuan

Penalaran Matematis Siswa SMA. Jurnal Pengajaran MIPA, 17 (1), 11.

Anggreavi, Efektivitas Model Pembelajaran Knisley Terhadap Kemampuan Pemahaman Matematis Peserta Didik Kelas X SMA Materi 
Pokok Trigonometri DiSMA N 8

Semarang Tahun Pelajaran

2015/2016. Semarang:

Universitas Islam Negeri

Walisongo.

Cahyani. Setyawati. 2016. Penetingnya

Peningkatan Kemampuan

Pemecahan Masalah Melaui PBL

untuk Mempersiapkan Generasi

Unggul Menghada MEA. Seminar

Nasional Matematika.154-155.

Kurunia. 2016. Analisis Kemampuan

Konsep Siswa Kelas VII

Berdasarkan Gaya Belajar dalam

Model Knisley. 25.

Kurunia. 2016. Analisis Kemampuan

Konsep Siswa Kelas VII

Berdasarkan Gaya Belajar dalam

Model Knisley. 20.

Masruroh. 2013. Meningkatkan Hasil

Belajar Matematika Materi

Kesebangunan Dengan

Menggunakan Media Mongkar

Pasang Bangun Datar Di Sekolah

Dasar. Jurnal Pendidikan Guru

Sekolah Dasar , 01(02),

Mujiati. Peningkatan Hasil Belajar

Matematika Melalui Metode

Discovery Learning Pada Materi

Konsep Keliling Dan Luas

Bangun Datar Siswa Kelas V A

SD Negeri 009 Pulau Kijang

Kecamatan Reter. Jurnal Primary

Program Studi Pendidikan Guru

Sekolah Dasar Dan Ilmu

Pendidikan, 6 (1).

Purnamasari. 2016. Penerapan Model

Knisley untuk Meningkatkan

Pemecahan Masalah Matematik

Siswa. Jurnal Analisa, 2 (2), 83.

Purwaningrum. 2018. Pakem Matematika.

Fadzilallah, Purwaningrum,

Wanabulandari. 2020.

Peningkatan Pemecahan Masalah

Matematis Melalui Model MMP

Berbantuan Modul Etnomatika

Pada Siswa Kelas IV SN

Wonosari. Jurnal Pendas, 5 (01) 